\title{
Lipid, fatty acid and protein utilization during lecithotrophic larval development of Lithodes santolla (Molina) and Paralomis granulosa (Jacquinot)
}

\author{
Gerhard Kattner $^{\mathrm{a}, *}$, Martin Graeve ${ }^{\mathrm{a}}$, Javier A. Calcagno ${ }^{\mathrm{b}}$, \\ Gustavo A. Lovrich ${ }^{\mathrm{c}}$, Sven Thatje ${ }^{\mathrm{a}}$, Klaus Anger ${ }^{\mathrm{d}}$ \\ a Alfred-Wegener-Institut für Polar-und Meeresforschung, Am Handelshafen 12, 27570 Bremerhaven, Germany \\ ${ }^{\mathrm{b}}$ Facultad de Ciencias Exactas y Naturales, Universidad de Buenos Aires, Buenos Aires, Argentina \\ ${ }^{\mathrm{c}}$ Centro Austral de Investigaciones Cientificas (CADIC), Ushuaia, Argentina \\ ${ }^{\mathrm{d}}$ Biologische Anstalt Helgoland, Stiftung Alfred-Wegener-Institut für Polar-und Meeresforschung, \\ 27498 Helgoland, Germany
}

Received 7 November 2002; received in revised form 28 January 2003; accepted 13 March 2003

\begin{abstract}
During the larval development of the subantarctic king crab, Lithodes santolla, and stone crab, Paralomis granulosa, we compared changes in the carbon, fatty acid and protein contents of larvae reared under constant conditions from hatching to metamorphosis, either in presence or absence of food (Artemia spp. nauplii). In both species the feeding condition had no influence on any of the chemical parameters studied, indicating a fully lecithotrophic (i.e. non-feeding) mode of development from hatching of the first zoea to metamorphosis of the late megalopa. Dry mass and carbon contents at hatching were similar in the larvae of both species, but L. santolla contained initially higher total amounts of fatty acids and protein than P. granulosa. Both species utilized considerable portions of their total fatty acid pool which decreased logarithmically throughout the time of development. At metamorphosis, it was almost exhausted in P. granulosa, while L. santolla had consumed only about $60 \%$. Protein utilization, in contrast, was higher in $L$. santolla $(40 \%)$ than in P. granulosa (20\%). Triacylglycerol was the principal storage lipid in both species, accounting initially for about $75 \%$ of the lipid fraction; it was strongly utilized during larval development. Phospholipid constituted the second largest lipid class; it also decreased in P. granulosa, but to a lesser extent in L. santolla. The major fatty acids of both species were 18:1(n-9), 20:5(n-3) and
\end{abstract}

\footnotetext{
* Corresponding author. Tel.: +49-471-4831-1490; fax: +49-471-4831-1425.
}

E-mail address: gkattner@awi-bremerhaven.de (G. Kattner). 
16:0 as well as, in lower proportions, 18:1(n-7), 22:6(n-3), 16:1(n-7) and 18:0. Monounsaturated fatty acids represented the dominant group in L. santolla, whereas $P$. granulosa contained similar amounts of mono- and polyunsaturated fatty acids. In L. santolla, monounsaturated fatty acids, especially 16:1(n-7), were preferentially utilized as compared to polyunsaturates. Due to a particularly strong lipid utilization in $P$. granulosa, all individual fatty acids were largely depleted at metamorphosis, showing similar extents of consumption. L. santolla had higher initial lipid and protein stores that seem to be used more economically as compared to P. granulosa.

(C) 2003 Elsevier Science B.V. All rights reserved.

Keywords: Lipids; Fatty acids; Protein; Lecithotrophy; Larval development; Lithodidae

\section{Introduction}

Marine organisms living in areas with scarce or highly variable food supply, for instance in high latitudes, are especially dependent on the storage of large lipid reserves (e.g. Clarke, 1983, 1993; Kattner and Hagen, 1995). Lipids are equally important during critical non-feeding developmental periods such as embryogenesis and metamorphosis (e.g. Anger et al., 1989; Kattner et al., 1994; Petersen and Anger, 1997). In subpolar regions, where productivity occurs in short seasonal pulses (see Knox, 1994), some lithodid crab species have evolved a non-feeding mode of larval development as a special adaptation to strong seasonality of planktonic food availability (Anger, 1996; Shirley and Zhou, 1997; Lovrich et al., 2003; Calcagno et al., in press).

Although extensive investigations have been carried out on the biology of commercially exploited lithodids (for reviews, see Dawson, 1989; Lovrich, 1997), little is generally known about the biochemical composition of their early life-history stages, particularly about the energy source of food-independent larvae. Detailed information on developmental changes in the elemental composition (carbon, nitrogen) of lecithotrophic larvae and feeding juveniles are available only for the northern stone crab, Lithodes maja (Anger, 1996). Similar studies were performed recently for the subantarctic congener Lithodes santolla (Lovrich et al., 2003) and another southern lithodid crab, Paralomis granulosa (Calcagno et al., in press). In all these species, the larvae are able to develop successfully from hatching to metamorphosis in complete absence of food; the only major difference is that $P$. granulosa passes through only two zoeal stages, while Lithodes spp. have three, in all cases followed by a benthic megalopal stage (see McLaughlin et al., 2001, 2003).

Although lipid deposits are generally the major energy source during non-feeding developmental periods in decapods (e.g. Herring, 1974; Holland, 1978; Amsler and George, 1984; Kattner et al., 1994; Wehrtmann and Kattner, 1998), practically nothing is known about the lipid content and composition of lecithotrophic lithodid crab larvae. Inferring from elemental and protein data, Anger (1996) estimated that lipids comprised about $30 \%$ of the dry mass of freshly hatched larvae of L. maja, and that about one half of these lipid reserves were catabolized during non-feeding development to metamorphosis. 
In the present study, we measured changes in the biochemical composition of the larvae of L. santolla and P. granulosa, both of which are commercially exploited and economically important lithodid crab species in the Magellan region of southern Argentina and Chile, and along the Chilean coast (Lovrich, 1997). Our major aims were (1) to compare biochemical changes in larvae reared in presence or absence of Artemia spp. nauplii in order to detect evidence for a possible ingestion and utilization of available food (facultative lecithotrophy), alternatively, lack of response to different feeding conditions should indicate a fully non-feeding mode of development (obligatory lecithotrophy); (2) to evaluate the utilization of internally stored lipids and proteins during lecithotrophic development. Special attention was paid to changes in the composition of lipids to elucidate possible preferences in the utilization of different lipid classes and individual fatty acids.

\section{Materials and methods}

The capture and maintenance of L. santolla and P. granulosa as well as the rearing of their larvae were described in detail by Lovrich et al. (2003) and Calcagno et al. (in press). Briefly, ovigerous females were collected in April 2000 in the Beagle Channel (southern Argentina), kept in flow-through seawater aquaria, and transported with the German Research Icebreaker "Polarstern" to the marine biological laboratory at Helgoland (Germany). Actively swimming larvae (freshly hatched, all from the same female) were randomly selected, and subsequently one individual was reared in 100-ml bowls under constant conditions of temperature $\left(6^{\circ} \mathrm{C}\right)$, salinity (32), and a $12: 12 \mathrm{~h}$ light/dark cycle. In two different experimental treatments, the larvae were reared either with or without addition of food (Artemia spp. nauplii; Argent Chemical Laboratories, USA). Water and (where applicable) food were changed daily, and the larvae were checked for moults or mortality.

Samples of larvae were collected for elemental and biochemical analyses immediately after hatching and later after different intervals of development (see Fig. 1). Dry mass and carbon determinations were performed with an autobalance (Mettler, UMT 2) and a Fisons Carlo Erba 1108 Elemental Analyser, respectively (for details, see Anger and Harms, 1990). Five measurements of one larva each were performed for each interval.

Protein measurements were made in triplicate samples with one individual each, using the Lowry method (Lowry et al., 1951) with bovine serum albumin as a standard. The protein data were converted to values of protein-bound carbon applying a factor of 0.5 , which is a realistic estimate based on the molecular structure of proteins and amino acids.

Due to the various chemical determinations carried out during the larval development, only one to three larvae per sample were available for lipid analyses. The larvae were homogenized and extracted in dichloromethane/methanol $(2: 1 ; \mathrm{v} / \mathrm{v})$ according to Folch et al. (1957). The lipid class compositions were determined by HPTLC and scanning densitometry (CAMAG TLC scanner III) after Olsen and Henderson (1989). Different commercial standard mixtures and lipid extracts from marine organisms were used for identification (Hagen, 1988). 
Lithodes santolla
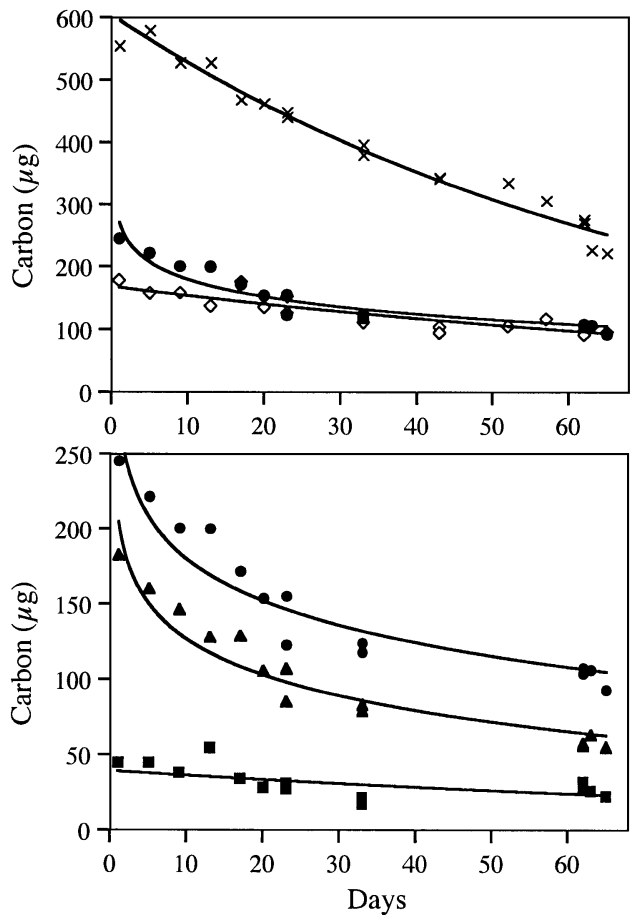

Paralomis granulosa
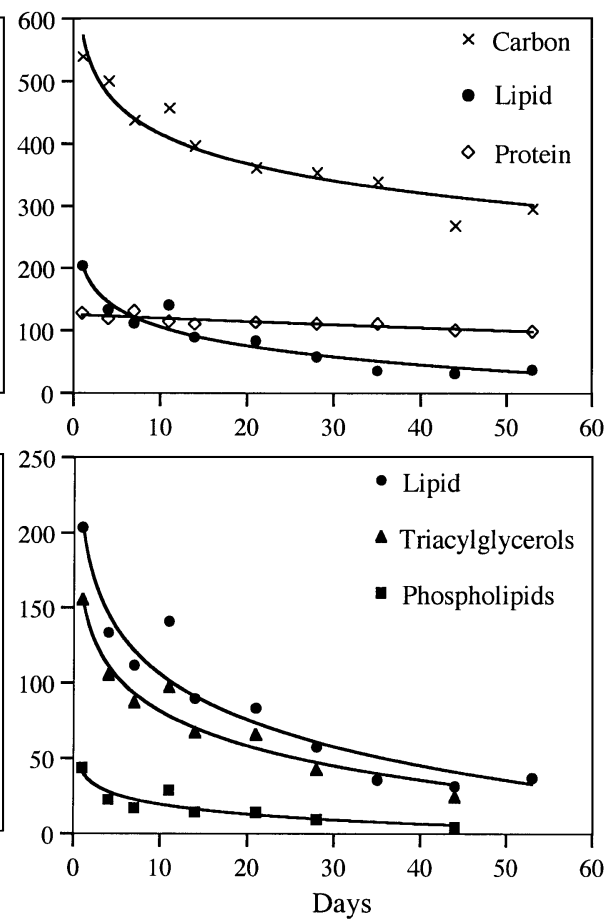

Fig. 1. L. santolla and P. granulosa. Changes in biochemical composition during lecithotrophic larval development; all data are converted to $\mu \mathrm{g}$ carbon (C) per larva. Carbon content with exponential fit for L. santolla $(y=595.43 \mathrm{e}-0.0134 x)$ and logarithmic fit for P. granulosa $(y=-68.038 \ln (x)+572.05)$; total lipid with logarithmic fit for L. santolla $(y=-39.967 \ln (x)+271.55)$ and P. granulosa $(y=-43.535 \ln (x)+205.85)$; protein with exponential fit for L. santolla $(y=168.13 \mathrm{e}-0.0091 x)$ and P. granulosa $(y=124.96 \mathrm{e}-0.0045 x)$; triacylglycerols with logarithmic fit for L. santolla $(y=-34.083 \ln (x)+204.92)$ and P. granulosa $(y=-32.709 \ln (x)+156.36)$; phospholipids with exponential fit for L. santolla $(y=39.348 \mathrm{e}-0.0081 x)$ and logarithmic fit for P. granulosa $(y=-9.3307 \ln (x)+41.019)$.

The fatty acid compositions were determined by gas chromatography (Kattner and Fricke, 1986). Briefly, fatty acids were converted to methyl esters by transesterification in methanol containing 3\% concentrated sulphuric acid at $80{ }^{\circ} \mathrm{C}$ for $4 \mathrm{~h}$. Fatty acid methyl esters were then analyzed with a gas liquid chromatograph (Chrompack 9000) on a 30 $\mathrm{m} \times 0.25 \mathrm{~mm}$ i.d. wall-coated open tubular column (film thickness: $0.25 \mu \mathrm{m}$; liquid phase: DB-FFAP) using temperature programming. Fatty acids were identified with standard mixtures and quantified by internal standard. If necessary, additional confirmation was carried out by GC-MS (Kattner et al., 1998).

Due to the small number of specimens available for lipid analysis, the determination of total lipids was not possible. To estimate the total lipid fraction, the mass of individual fatty acids was summed, which is a slight underestimation. Fatty acid carbon was calculated according to the molecular structure of fatty acids which consist on average of $75 \%$ carbon. 


\section{Results}

The larval development of $L$. santolla was monitored for a period of 62 days after hatching. The first juvenile stage was collected on day 63. Samples of P. granulosa were available only until day 52, although larval development averages about 61 days (Calcagno et al., in press). Hence, biomass losses occurring during the final ca. 9 days of megalopal development could not be measured, implying that our data underestimate the actual losses from hatching to metamorphosis. When values for fed and unfed larvae were compared in each species, no significant differences were found in dry mass, elemental composition, protein content, or in quantity or composition of the lipid fraction (two-way ANOVA with time of development and treatment as factors). While our results showed in both species a highly significant influence of development time, there was no significant effect of presence or absence of food, nor was there an interaction between the factors time and feeding condition. Thus, there was no indication of ingestion and utilization of food, i.e. the larvae of both species did not eat, regardless of food availability. Therefore, the data from both treatments were subsequently pooled for each species to analyze the effect of development time on the biochemical composition of the lithodid larvae.

\subsection{Lithodes santolla}

During the larval development of L. santolla from the freshly hatched zoea I to the late megalopa (62 days), dry mass decreased by $28 \%$ from about 1040 to $750 \mu \mathrm{g}$ per individual and then dropped sharply to $580 \mu \mathrm{g}$ in the first juvenile stage, which is a reduction of $16 \%$. This decline in dry mass towards the juvenile was due to the loss of the exuviae, which is highest at metamorphosis (Lovrich et al., 2003). The utilization of total carbon, protein and fatty acids during the time of larval development is shown in Fig. 1; for more immediate comparison, all biochemical data are converted to carbon (C) values. Total $\mathrm{C}$ amounted initially to about one half of larval dry mass. It decreased from about $550 \mu \mathrm{g}$ in the zoea I to $270 \mu \mathrm{g}$ in the late megalopa, corresponding to a loss of $53 \%$. The loss in total $\mathrm{C}$ towards the juvenile from 270 to $220 \mu \mathrm{g}$ was less pronounced than in dry mass resulting in a total loss of $\mathrm{C}$ from zoea I to juvenile of about $61 \%$. Overall, the total $\mathrm{C}$ content was more reduced than dry mass. This decrease was best described as an exponential function of the time of development $\left(r^{2}=0.9561\right.$; Fig. 1).

The protein content decreased from about $350 \mu \mathrm{g}$ per larva in the zoea I to $200 \mu \mathrm{g}$ in the late megalopal and first juvenile stage, representing a loss of about $40 \%$. The initial proportion of protein-C made up on average $15 \%$ of dry mass. The proportion of protein-C made up on average $33 \%$ of total $\mathrm{C}$ during development to the late megalopal stage, but in the juvenile stage the proportion was higher comprising $45 \%$ of total $\mathrm{C}$. The decrease in protein-C with developmental time was similar to that of total $\mathrm{C}$ decreasing exponentially $\left(r^{2}=0.7998\right)$, but this pattern was here closer to a linear $\left(r^{2}=0.7799\right)$ than to a logarithmic relationship $\left(r^{2}=0.7222\right)$ (Fig. 1).

Total fatty acid C comprised about $24 \%$ of dry mass and $44 \%$ of total $\mathrm{C}$ immediately after hatching. The total fatty acid content per individual decreased from about 250 to 100 
$\mu \mathrm{g}$ C (loss of about $60 \%$ ) during development from hatching to the late megalopa without further decrease to the juvenile. The loss of lipid-C was more pronounced during the zoeal phase than in the megalopa. This decrease with time was best reflected by a logarithmic $\left(r^{2}=0.8926\right)$ or exponentially fit $\left(r^{2}=0.8519\right)$ (Fig. 1).

The major lipid classes of L. santolla were triacylglycerols (neutral lipids) and phospholipids (polar lipids), which together comprised about $85 \%$ of total lipid. Triacylglycerols alone contributed initially ca. $70-75 \%$ to the total lipid fraction, but this proportion decreased during development to the late megalopa and early juvenile stage to about $55-60 \%$. The amounts of triacylglycerol-C per individual decreased logarithmically from $180 \mu \mathrm{g}$ at hatching to about $60 \mu \mathrm{g} \mathrm{C}$ in the late megalopa and freshly metamorphosed juvenile $\left(r^{2}=0.9163\right)$, which is a loss of $67 \%$. The phospholipid fraction decreased to a lesser extent, from about 45 to $26 \mu \mathrm{g} \mathrm{C}$ per larva (i.e. by $42 \%$ ) with only low statistical significance (Fig. 1).

The major fatty acids of $L$. santolla were 18:1(n-9) and 20:5(n-3), comprising up to $30 \%$ and $28 \%$ of total fatty acids, respectively, followed by 16:0, 18:1(n-7), 22:6(n-3), 16:1(n-7) and 18:0. Other fatty acids occurred only in small amounts (Table 1).

Table 1

Lithodes santolla

\begin{tabular}{|c|c|c|c|c|c|c|}
\hline \multirow[t]{2}{*}{ Fatty acids } & \multirow{2}{*}{$\begin{array}{l}\begin{array}{l}\text { Zoea } \\
(\text { days } 0-20)\end{array} \\
\begin{array}{l}\text { Mean } \pm \text { S.D. } \\
(7)\end{array}\end{array}$} & \multirow{2}{*}{$\begin{array}{l}\text { Megalopa (woA) } \\
\text { (days 22, 32, 42) } \\
\begin{array}{l}\text { Mean } \pm \text { S.D. } \\
(3)\end{array}\end{array}$} & \multirow{2}{*}{$\begin{array}{l}\text { Megalopa (wA) } \\
(\text { days 32, 42) } \\
\text { Mean } \pm \text { S.D. } \\
(2)\end{array}$} & \multirow{2}{*}{$\begin{array}{l}\text { Megalopa (woA) } \\
\text { (days 56, 62) } \\
\begin{array}{l}\text { Mean } \pm \text { S.D. } \\
(2)\end{array}\end{array}$} & \multirow{2}{*}{$\begin{array}{l}\text { Megalopa (wA) } \\
(\text { days 52, 62) } \\
\begin{array}{l}\text { Mean } \pm \text { S.D. } \\
(2)\end{array}\end{array}$} & \multirow{2}{*}{$\begin{array}{l}\begin{array}{l}\text { Juvenile } \\
\text { (days 63, 65) }\end{array} \\
\text { Mean } \pm \text { S.D. } \\
\text { (2) }\end{array}$} \\
\hline & & & & & & \\
\hline $14: 0$ & $0.9 \pm 0.3$ & $0.5 \pm 0.4$ & $0.8 \pm 0.0$ & $0.3 \pm 0.0$ & $0.1 \pm 0.1$ & $0.3 \pm 0.1$ \\
\hline $16: 0$ & $15.7 \pm 0.6$ & $16.6 \pm 0.6$ & $16.0 \pm 0.2$ & $12.2 \pm 0.4$ & $12.5 \pm 0.2$ & $14.1 \pm 0.1$ \\
\hline $16: 1(n-7)$ & $5.4 \pm 0.5$ & $5.0 \pm 0.7$ & $5.1 \pm 0.1$ & $2.4 \pm 0.5$ & $2.4 \pm 0.4$ & $2.2 \pm 0.4$ \\
\hline $16: 2$ & $0.4 \pm 0.2$ & $0.2 \pm 0.3$ & $0.2 \pm 0.3$ & $0.1 \pm 0.1$ & $0.1 \pm 0.1$ & - \\
\hline $16: 3$ & $0.5 \pm 0.1$ & $0.2 \pm 0.4$ & $0.3 \pm 0.5$ & $0.2 \pm 0.0$ & $0.2 \pm 0.0$ & $0.2 \pm 0.0$ \\
\hline $16: 4$ & $0.1 \pm 0.2$ & - & - & - & - & - \\
\hline $18: 0$ & $5.1 \pm 1.6$ & $5.0 \pm 0.7$ & $4.8 \pm 0.3$ & $4.6 \pm 0.2$ & $5.2 \pm 0.5$ & $6.4 \pm 0.7$ \\
\hline $18: 1(n-9)$ & $28.4 \pm 1.5$ & $29.7 \pm 0.9$ & $30.5 \pm 0.6$ & $24.7 \pm 1.4$ & $26.4 \pm 0.7$ & $26.0 \pm 1.3$ \\
\hline $18: 1(n-7)$ & $11.0 \pm 1.0$ & $12.5 \pm 0.3$ & $12.2 \pm 0.5$ & $10.1 \pm 0.3$ & $10.9 \pm 0.3$ & $10.7 \pm 0.7$ \\
\hline $18: 2(n-6)$ & $1.3 \pm 0.9$ & $1.1 \pm 0.1$ & $1.1 \pm 0.1$ & $1.1 \pm 0.2$ & $0.8 \pm 0.0$ & $1.4 \pm 0.7$ \\
\hline $18: 3(n-3)$ & $0.5 \pm 0.1$ & $0.9 \pm 0.3$ & $0.3 \pm 0.5$ & $0.3 \pm 0.0$ & $0.3 \pm 0.0$ & $0.3 \pm 0.1$ \\
\hline $18: 4(n-3)$ & $0.6 \pm 0.2$ & $0.3 \pm 0.3$ & $0.3 \pm 0.4$ & $0.2 \pm 0.1$ & $0.2 \pm 0.1$ & $0.2 \pm 0.0$ \\
\hline $20: 1(n-9)$ & $1.7 \pm 0.1$ & $1.8 \pm 0.1$ & $2.0 \pm 0.4$ & $1.6 \pm 0.1$ & $1.4 \pm 0.1$ & $1.4 \pm 0.3$ \\
\hline $20: 1(n-7)$ & $1.1 \pm 0.2$ & $1.2 \pm 0.0$ & $1.6 \pm 0.4$ & $0.9 \pm 0.0$ & $1.1 \pm 0.1$ & $1.1 \pm 0.1$ \\
\hline $20: 4(n-6)$ & $0.8 \pm 1.1$ & $0.1 \pm 0.2$ & $0.2 \pm 0.3$ & $2.3 \pm 0.1$ & $2.5 \pm 0.1$ & $2.3 \pm 0.1$ \\
\hline $20: 4(n-3)$ & $0.8 \pm 0.1$ & $0.5 \pm 0.4$ & $0.3 \pm 0.5$ & $0.6 \pm 0.1$ & $0.6 \pm 0.1$ & $0.5 \pm 0.1$ \\
\hline $20: 5(n-3)$ & $17.9 \pm 1.9$ & $16.7 \pm 0.7$ & $17.4 \pm 0.9$ & $28.2 \pm 2.6$ & $23.9 \pm 1.0$ & $21.9 \pm 1.8$ \\
\hline $22: 5(n-3)$ & $0.3 \pm 0.7$ & - & - & $1.0 \pm 0.1$ & $1.1 \pm 0.0$ & $1.1 \pm 0.0$ \\
\hline $22: 6(n-3)$ & $6.5 \pm 0.7$ & $6.3 \pm 0.2$ & $5.8 \pm 1.2$ & $8.4 \pm 0.2$ & $9.4 \pm 0.5$ & $8.7 \pm 0.5$ \\
\hline SAT & $22.0 \pm 2.3$ & $22.1 \pm 0.9$ & $21.6 \pm 0.1$ & $17.2 \pm 0.2$ & $18.1 \pm 0.2$ & $21.0 \pm 0.4$ \\
\hline MUFA & $48.3 \pm 2.2$ & $51.5 \pm 0.4$ & $52.5 \pm 1.9$ & $39.7 \pm 2.2$ & $42.1 \pm 0.7$ & $40.6 \pm 0.9$ \\
\hline PUFA & $29.8 \pm 1.9$ & $26.4 \pm 0.7$ & $26.0 \pm 2.1$ & $43.1 \pm 2.5$ & $39.8 \pm 0.9$ & $37.3 \pm 2.0$ \\
\hline
\end{tabular}

Fatty acid compositions (mass $\%$ of total fatty acids) of larval stages and first juvenile, fed without (woA) and with (wA) Artemia nauplii presented as mean and standard deviation (S.D.); saturated (SAT), monounsaturated (MUFA) and polyunsaturated (PUFA) fatty acids; $(n)$ number of samples. 
Monounsaturated fatty acids were the major group, mostly due to the dominance of 18:1(n-9). Zoea and early megalopal larvae of $L$. santolla had a similar composition. A clear change, namely an increasing dominance of polyunsaturated fatty acids, became visible in the late megalopa and juvenile. The relative increase in 20:5(n-3) and 22:6(n-3) was probably due to the proportional increase of remaining phospholipids in relation to triacylglycerols in the older stages. While total fatty acids decreased by about $60 \%$, the losses varied among individual fatty acids. Monounsaturated fatty acids were preferably utilized, especially $16: 1(n-7)$, decreasing by $>80 \%$, followed by the two $18: 1$ isomers. Only about $22 \%$ of the polyunsaturated fatty acid $20: 5(n-3)$ and $30 \%$ of 22:6(n-3) were utilized from hatching to the late megalopa; including the development to juvenile the loss was $40 \%$ for $20: 5(n-3)$ and $30 \%$ for $22: 6(n-3)$. Since no differences were found between fed and unfed larvae, the data from the two treatments could be pooled (Fig. 2).

\subsection{Paralamis granulosa}

Total dry mass and carbon content of the first larval stage of $P$. granulosa were slightly lower than in L. santolla. Also the decrease in dry mass observed during larval development from hatching to the late megalopa was weaker in P. granulosa (from 985 to $764 \mu \mathrm{g}$ per individual, corresponding to a loss of $22 \%$ ). The ratio of total $\mathrm{C}$ to dry mass was roughly the same in both species.

The losses of total $\mathrm{C}$, protein and total fatty acids are presented in Fig. 1. Nearly half of the $\mathrm{C}$ initially present was lost during larval development of $P$. granulosa, comparable to L. santolla, decreasing from about 540 to $280 \mu \mathrm{g} \mathrm{C}$ per individual. This decrease can be fit
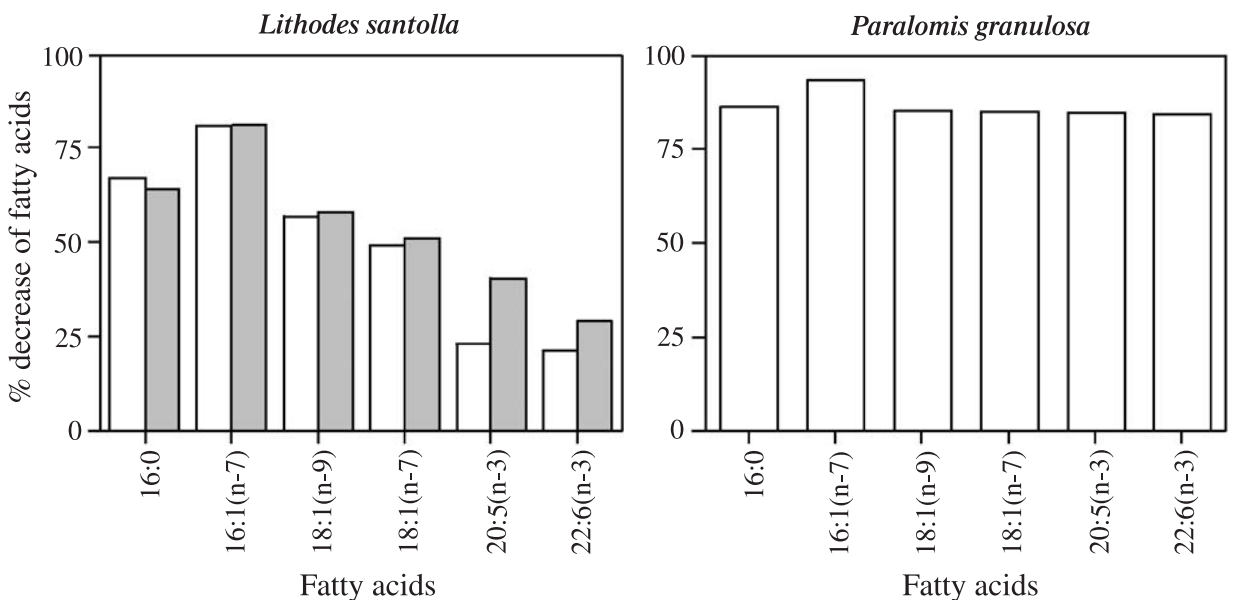

Fig. 2. L. santolla and P. granulosa. Fatty acid utilization during lecithotrophic larval development, expressed as percentage decrease of major individual fatty acids (mean data from experiments with fed and unfed larvae). Decrease was calculated from fatty acid amount of zoea after hatching (day 0) and latest megalopa analyzed (day 62 for L. santolla and day 52 for P. granulosa) (open bars). In addition, the same calculation is presented until the juvenile stage of L. santolla (gray bars). 
almost equally well using either a logarithmic $\left(r^{2}=0.9089\right)$ or an exponential function $\left(r^{2}=0.8997\right)$.

The protein content per individual decreased moderately from hatching to the late megalopal stage, from 260 to $200 \mu \mathrm{g}$ (or from 128 to $100 \mu \mathrm{g}$ protein-C), representing a loss of about $22 \%$. This decrease follows an exponential $\left(r^{2}=0.7920\right)$ or a linear trend $\left(r^{2}=0.7673\right)$, comparable with the pattern observed in L. santolla (Fig. 1). The proportion of protein- $\mathrm{C}$ within total dry mass remained almost constant at $13.4 \%$, whereas the percentage of protein- $\mathrm{C}$ to total $\mathrm{C}$ increased from $24 \%$ in the zoea I to $35 \%$ in the megalopa. This differs conspicuously from L. santolla, where the percentage of protein-C remained almost constant.

The fraction of total fatty acid $\mathrm{C}$ within dry mass or total $\mathrm{C}$ in hatching $P$. granulosa was lower than in L. santolla, accounting for about $20 \%$ and $30 \%$, respectively. These proportions decreased to about $5 \%$ and $12 \%$ in the late megalopa. The utilization of lipids was higher in P. granulosa than in L. santolla. From the first zoeal to the late megalopal stage, the content of total fatty acid $\mathrm{C}$ declined from 270 to about $50 \mu \mathrm{g} \mathrm{C}$ per larva, or by about $81 \%$. A major part of the decrease in total fatty acids occurred during the first $10-15$ days of development. This pattern could be described with a logarithmic $\left(r^{2}=0.9200\right)$ or an exponential fit $\left(r^{2}=0.8947\right)$. Very similar patterns were found also in total $\mathrm{C}$, showing that these two parameters are closely linked.

Table 2

Paralomis granulosa

\begin{tabular}{lccc}
\hline Fatty acids & \multicolumn{1}{c}{ Zoea } & Megalopa (woA) & Megalopa (wA) \\
\cline { 2 - 4 } & Mean \pm S.D. (5) & Mean \pm S.D. (3) & Mean \pm S.D. (2) \\
\hline $14: 0$ & $1.3 \pm 0.1$ & $1.3 \pm 0.1$ & $1.1 \pm 0.1$ \\
$16: 0$ & $15.7 \pm 0.6$ & $15.3 \pm 0.9$ & $15.5 \pm 2.4$ \\
$16: 1(n-7)$ & $5.5 \pm 0.4$ & $4.1 \pm 1.7$ & $4.0 \pm 0.2$ \\
$16: 2$ & $0.9 \pm 0.3$ & $1.5 \pm 0.6$ & $1.1 \pm 0.0$ \\
$16: 3$ & $0.8 \pm 0.1$ & $0.7 \pm 0.1$ & $0.9 \pm 0.3$ \\
$16: 4$ & $0.5 \pm 0.0$ & $0.9 \pm 0.2$ & $0.4 \pm 0.5$ \\
$18: 0$ & $5.1 \pm 1.5$ & $5.7 \pm 1.0$ & $6.2 \pm 0.2$ \\
$18: 1(n-9)$ & $19.6 \pm 0.8$ & $19.8 \pm 0.2$ & $20.5 \pm 0.9$ \\
$18: 1(n-7)$ & $9.5 \pm 0.2$ & $9.3 \pm 0.3$ & $10.4 \pm 0.2$ \\
$18: 2(n-6)$ & $1.3 \pm 0.1$ & $1.5 \pm 0.2$ & $2.0 \pm 0.8$ \\
$18: 3(n-3)$ & $0.6 \pm 0.0$ & $0.5 \pm 0.0$ & $0.6 \pm 0.2$ \\
$18: 4(n-3)$ & $0.5 \pm 0.1$ & $0.4 \pm 0.1$ & $0.5 \pm 0.4$ \\
$20: 1(n-9)$ & $1.1 \pm 0.1$ & $1.5 \pm 0.3$ & $1.8 \pm 0.4$ \\
$20: 1(n-7)$ & $0.8 \pm 0.0$ & $1.0 \pm 0.2$ & $1.0 \pm 0.1$ \\
$20: 4(n-6)$ & $5.9 \pm 0.2$ & $6.7 \pm 0.6$ & $3.7 \pm 4.2$ \\
$20: 4(n-3)$ & $0.6 \pm 0.2$ & $0.6 \pm 0.2$ & $0.6 \pm 0.2$ \\
$20: 5(n-3)$ & $15.1 \pm 0.5$ & $14.8 \pm 0.4$ & $16.4 \pm 3.1$ \\
$22: 5(n-3)$ & $2.0 \pm 0.1$ & $2.2 \pm 0.3$ & $1.1 \pm 1.6$ \\
$22: 6(n-3)$ & $11.9 \pm 0.7$ & $11.3 \pm 0.3$ & $11.0 \pm 1.7$ \\
SAT & $22.9 \pm 2.0$ & $23.0 \pm 1.1$ & $23.5 \pm 2.8$ \\
MUFA & $36.9 \pm 1.2$ & $35.8 \pm 1.9$ & $38.2 \pm 1.9$ \\
PUFA & $40.2 \pm 1.3$ & $41.2 \pm 1.8$ & $38.3 \pm 4.7$ \\
\hline Fatty & & 5.2 & 1.9
\end{tabular}

Fatty acid composition (mass \% of total fatty acids) of larval stages, fed without (woA) and with (wA) Artemia nauplii presented as mean and standard deviation (S.D.); for abbreviations refer to Table 1. 
As in L. santolla, triacylglycerols also were the major lipid class in P. granulosa, contributing on average $75 \%$ to total lipids, while the proportion of phospholipids was only about $17 \%$. Triacylglycerols were utilized by more than $80 \%$, decreasing during larval development from about 200 to $32 \mu \mathrm{g}$ per individual. The same trend was observed in phospholipids. This is different from L. santolla where proportionally less triacylglycerols and only small amounts of phospholipids were utilized. The losses in triacylglycerols and phospholipids were best fitted by exponential $\left(r^{2}=0.9509\right.$ and $r^{2}=0.8737$, respectively) or logarithmic functions $\left(r^{2}=0.9462\right.$ and $\left.r^{2}=0.8307\right)$ (Fig. 1).

The same principal fatty acids as in L. santolla occurred also in P. granulosa, but with different proportions. Mono- and polyunsaturated fatty acids contributed $36 \%$ and $41 \%$, respectively, while only $23 \%$ of the total fatty acid pool were saturates. The major fatty acids were 18:1(n-9), 16:0 and 20:5(n-3), occurring in similar quantities each comprising up to $20 \%$ of total fatty acids. $22: 6(n-3), 18: 1(n-7), 16: 1(n-7)$ and, in contrast to L. santolla, also 20:4(n-6) occurred in considerable amounts (up to $7 \%$ ). No significant changes in the fatty acid composition were observed during development or between fed and unfed larvae (Table 2). Due to the strong utilization of lipids during larval development, all fatty acids were in this species considerably depleted. When metamorphosis was approached, 16:1(n-7) was almost exhausted, while polyunsaturates had been utilized to a slightly lesser extent (Fig. 2).

\section{Discussion}

Experimental evidence of food-independent larval development (lecithotrophy) has been shown for several lithodid crab species, namely L. maja (Anger, 1996), L. aequispinus (Shirley and Zhou, 1997), L. santolla (McLaughlin et al., 2001; Lovrich et al., 2003), and P. granulosa (McLaughlin et al., 2003; Calcagno et al., in press). This reproductive trait, which is quite unusual among the marine decapod crustaceans (for review, see Gore, 1985; Rabalais and Gore, 1985; Anger, 2001), is based on an enhanced female energy allocation per offspring, i.e. the production of large yolky eggs. Since most examples of lecithotrophy have been observed in subpolar regions, this trait has been interpreted as an adaptation to strong seasonality in planktonic food availability with only short pulses of productivity in summer (for recent discussion, see Anger et al., 2003; Thatje et al., 2003). Hence, lecithotrophic larvae may be expected to occur also in other lithodid species as well as in other decapods living in high latitudes (Anger, 1996, 2001). While this generalization is supported by large egg size frequently observed in subpolar species, comparative experimental evidence of lecithotrophic life histories is largely missing.

Our results on lipid and fatty acid composition of the early life-history stages of $L$. santolla and P. granulosa provide evidence for lecithotrophy throughout larval development from hatching to metamorphosis. This food-independent mode of development is based on unusually high initial organic reserves, mainly on enhanced lipid stores remaining from the egg yolk (for recent review and comparison with planktotrophic decapod larvae, see Anger, 2001). Since food availability did not result in an increase (or in a lower rate of decrease) in dry mass, total carbon, or in the fatty acid content, and no 
differences in the fatty acid composition of fed and unfed larvae were found, our data indicate consistently that the larvae of both species are fully non-feeding (obligatory lecithotrophy). Although the last few days prior to metamorphosis in P. granulosa were not covered, which could allow for a slight doubt as to the degree of lecithotrophy during the final phase of larval development in this species, observations of larval mortality, development duration and mouthpart morphology (McLaughlin et al., 2003) as well as more complete data of their elemental composition (total $\mathrm{C}, \mathrm{N}, \mathrm{C} / \mathrm{N}$ ratio; Calcagno et al., in press) support our conclusion that all larval stages are non-feeding. First food uptake and growth have consistently been observed after metamorphosis, i.e. in the first juvenile crab stage (Lovrich et al., 2003; Calcagno et al., in press).

Studies of the elemental composition of lithodid larvae suggested that lipid reserves remaining from the egg yolk should provide the principal energy source for non-feeding development (Anger, 1996). Our study provides now the first direct biochemical evidence for this inferred assumption. Already for embryogenesis a considerable amount of the initially available egg lipids is invested. As known from most planktotrophic marine decapod species utilization rates vary from about 25 to $60 \%$ of total lipid among species from different climatic zones (Anger and Harms, 1990; Wehrtmann and Kattner, 1998; Wehrtmann and Graeve, 1998; Anger, 2001; Graeve and Wehrtmann, 2003; Morais et al., 2002). In the eggs of L. maja, about one third of the initial total C content is utilized during embryogenesis (Anger, 1996). Thus, species with a lecithotrophic larval development have to furnish their eggs with an enhanced lipid pool which may comprise at least $40 \%$ of dry mass to cope with the extended period of non-feeding development. Comparable large eggs contain up to $40 \%$ of lipid (Herring, 1974).

Although size, dry mass and C contents were similar in freshly hatched zoeal larvae of L. santolla and P. granulosa, the initial lipid content was about $20 \%$ higher in L. santolla. Its zoeal development is comprised of three stages lasting together about 22 days (at constant $6{ }^{\circ} \mathrm{C}$ ), while the megalopal stage alone requires ca. 40 days (Lovrich et al., 2003). In $P$. granulosa, by contrast, there are only two zoeal stages which require in total about 16 days, followed by a megalopa which requires another ca. 45 days to reach metamorphosis (Calcagno et al., in press). The pattern of lipid utilization during the time of development may be described as a logarithmic decrease in total fatty acids. According to the fitted equation, the three zoeal stages of $L$. santolla combined utilized within 22 days about $46 \%$ of the total fatty acid pool that was present at hatching, whereas the megalopa used only $15 \%$ of the lipids within the following 40 days. For $P$. granulosa, the same calculation results in a utilization rate of 59\% for the zoeae (with only two stages and 16 days of development), while another $28 \%$ was utilized during the 45 days of development through the megalopal stage. These estimates are very similar to the losses that were measured directly during the period from hatching to metamorphosis. According to these data, $60 \%$ of the total fatty acid pool were consumed in L. santolla and $81 \%$ in P. granulosa (in the latter species measured only until day 52, suggesting that yet higher losses may occur until metamorphosis). The differences in the percentage utilization of total fatty acids are partly due to the differences in the initial amounts of fatty acids in the first zoeal stages, which were lower in P. granulosa than in L. santolla.

As in the total lipids fraction, the amount of proteins measured at hatching was lower in P. granulosa than in L. santolla. However, L. santolla utilized during its larval develop- 
ment twice as much of its initially available protein (about $40 \%$ vs. $20 \%$ ), coinciding with a lower utilization of lipids. A nearly linear pattern of protein degradation shows that this fraction was not preferentially utilized during zoeal development. Hence, L. santolla appears to utilize the two principal biochemical fractions of its biomass in a more balanced fashion as energy sources, which makes it less dependent on lipids than P. granulosa. On the other hand, freshly hatched L. santolla larvae contained more lipids than P. granulosa. In the latter species, lipids were almost exhausted shortly before metamorphosis, while proteins had hardly been used. This difference is confirmed also by measurements of the $\mathrm{C} / \mathrm{N}$ ratio at metamorphosis, which was lower in P. granulosa than in L. santolla.

Triacylglycerols, which are generally considered as the principal storage lipid, constituted the major lipid class in both species, whereas phospholipids, which are typical membrane lipids, were less abundant. The utilization of lipids was thus closely related to that of triacylglycerols. As shown also for total fatty acids, these two lipid classes were utilized less by $L$. santolla than by $P$. granulosa. In the latter, phospholipids also decreased logarithmically during larval development. A high proportion of triacylglycerols, which is the most important energy source, may thus be typical of lecithotrophic larvae, whereas the lipids in the eggs and larvae of other decapod species are often dominated by phospholipids (Clarke, 1977, 1979, 1993; Kattner et al., 1994; Wehrtmann and Graeve, 1998; Graeve and Wehrtmann, 2003).

The fatty acid composition of the larval stages of $L$. santolla and P. granulosa are not essentially different from that in other decapod larvae (e.g. Levine and Sulkin, 1984; Clarke et al., 1990; Kattner et al., 1994; Graeve et al., 1997). Higher proportions of monounsaturates in L. santolla are probably due to the higher amounts of triacylglycerols. Due to stronger utilization of lipids by $P$. granulosa as compared to L. santolla, interspecific differences occurred in the overall consumption of individual fatty acids. In both species, monounsaturated fatty acids were preferentially catabolized during larval development, with strongest utilization of 16:1(n-7) followed by degradation of the 18:1 isomers. A preferential catabolism of monounsaturates may be generalized, as other investigations on fatty acid utilization during embryogenic and larval development of decapods show consistently the same pattern (Rainuzzo et al., 1997; Wehrtmann and Graeve, 1998; Wehrtmann and Kattner, 1998; Morais et al., 2002). In P. granulosa the polyunsaturated fatty acids 20:5(n-3) and 22:6(n-3) were largely depleted when metamorphosis was imminent, indicating the crucial importance of immediate feeding in the first juvenile crab stage. In L. santolla, however, the amount of polyunsaturates decreased only slightly during development to the late megalopa and through metamorphosis to the first juvenile stage, so that their proportions within the total fatty acid pool increased. In general, polyunsaturates are essential components in marine organisms, because they play the central role in the buildup and maintenance of membranes, requiring that they are used less for energetic demands but conserved for membrane differentiation. Since P. granulosa has lower initial lipid reserves than L. santolla and, moreover, it is apparently less capable of utilizing its protein stores for additional energy production, this species appears to approach more closely its ultimate limits of lecithotrophy.

In summary, we found clear interspecific differences in the utilization patterns of lipids and proteins of two subantarctic lithodid species with fully lecithotrophic larvae. As a major difference in their life cycles, these species show different degrees of abbreviation of 
the zoeal phase (two stages in P. granulosa, three in L. santolla). As a consequence of longer stage durations in $P$. granulosa, however, the total period of larval development from hatching to the first juvenile crab stage is roughly the same in both species. Generally, the utilization of lipids was much more pronounced during the actively swimming zoeal phase than in the benthic megalopa. In L. maja, which shows similar behavioral changes during its larval development, this change in larval activity was clearly reflected by high rates of oxygen consumption in the zoeae followed by low metabolic rates in the megalopa (Anger, 1996).

L. santolla contained higher initial amounts of storage compounds, which were used more economically. Namely, a stronger use of protein reserves allowed for spare use of lipids. In P. granulosa, on the other hand, lipids were nearly depleted shortly before metamorphosis. Hence, the eggs and early larvae of L. santolla appear to be better prepared for non-feeding development than those of P. granulosa, and the first juvenile crab stage of $L$. santolla may thus depend less on benthic food availability. However, the initial furnishing of eggs with lipids may be intraspecifically highly variable, depending on season, population, size, age or physiological condition (feeding status) of the female and, possibly, other internal and/or environmental factors. This is suggested by observations of significant variability in the carbon content of eggs and larvae produced by different females of L. maja (Anger, 1996). The extent and the consequences of intraspecific variability in egg size and biochemistry of L. santolla and P. granulosa as well as in other possibly lecithotrophic lithodid species living in high latitudes remains to be further elucidated.

\section{Acknowledgements}

We would like to thank C. Harms, M. Böer, A. Kaffenberger and C. Püschel for analytical work. We greatly appreciate the help of the crew of PFS "Polarstern" during the transport of live crabs. E. Heyer and R. Hottung helped in maintaining larval cultures. Javier Calcagno is grateful to the German Academic Exchange Service (DAAD) for funding his research visit to Helgoland. This project was partially funded by the International Bureau of the German Ministry of Scientific Research (BMBF, project No. ARG 99/002), and the Argentine Secretaría Nacional para la Tecnología, Ciencia e Inovación Productiva (SETCIP). [SS]

\section{References}

Amsler, M.O., George, R.Y., 1984. Seasonal variation in the biochemical composition of the embryos of Callinectes sapidus Rathbun. J. Crustac. Biol. 4, 546-553.

Anger, K., 1996. Physiological and biochemical changes during lecithotrophic larval development and early juvenile growth in the northern stone crab, Lithodes maja (Decapoda: Anomura). Mar. Biol. 126, 283 - 296.

Anger, K., 2001. The biology of decapod crustacean larvae. A.A. Balkema Publishers, Sweets and Zeitlinger BV, Lisse, ISSN 0168-6456. Crustacean Issues 14, pp. 1-420.

Anger, K., Harms, J., 1990. Elemental (CHN) and proximate biochemical composition of decapod crustacean larvae. Comp. Biochem. Physiol. 97B, 69-80. 
Anger, K., Harms, J., Püschel, C., Seeger, B., 1989. Physiological and biochemical changes during larval development of a brachyuran crab reared under constant conditions in the laboratory. Helgol. Meeresunters. $43,225-244$.

Anger, K., Thatje, S., Lovrich, G.A., Calcagno, J.A., 2003. Larval and early juvenile development of Paralomis granulosa reared at different temperatures: tolerance of cold and food limitation in a lithodid crab from high latitudes. Mar. Ecol. Prog. Ser. (in press).

Calcagno, J.A., Thatje, S., Anger, K., Lovrich, G.A., Kaffenberger, A., 2003. Changes in biomass and chemical composition during lecithotrophic larval development of the southern stone crab, Paralomis granulosa (Jacquinot). Mar. Ecol. Prog. Ser. (in press).

Clarke, A., 1977. Lipid class and fatty acid composition of Chorismus antarcticus (Pfeffer) (Crustacea: Decapoda) at South Georgia. J. Exp. Mar. Biol. Ecol. 28, 297-314.

Clarke, A., 1979. Lipid content and composition of the pink shrimp Pandalus montagui (Leach) (Crustacea: Decapoda) at South Georgia. J. Exp. Mar. Biol. Ecol. 38, 1-17.

Clarke, A., 1983. Life in cold water: the physiological ecology of polar marine ectotherms. Oceanogr. Mar. Biol. Ann. Rev. 21, 341-453.

Clarke, A., 1993. Egg size and egg composition in polar shrimps (Caridea: Decapoda). J. Exp. Mar. Biol. Ecol. $168,189-203$.

Clarke, A., Brown, J.H., Holmes, L.J., 1990. The biochemical composition of eggs from Macrobrachium rosenbergii in relation to embryonic development. Comp. Biochem. Physiol. 96, 505-511.

Dawson, E.W., 1989. King crabs of the world (Crustacea: Lithodidae) and their fisheries: a comprehensive bibliography. Misc. Publ. 101. New Zealand Oceanogr. Inst., Div. Water Sci., DSIR, Wellington.

Folch, J., Lees, M., Sloane-Stanley, G.H., 1957. A simple method for the isolation and purification of total lipides from animal tissues. J. Biol. Chem. 226, 497-509.

Gore, R.H., 1985. Molting and growth in decapod larvae. In: Wenner, A.M. (Ed.), Larval Growth. Crustacean Issues, vol. 2. Balkema, Rotterdam, pp. 1-65.

Graeve, M., Wehrtmann, I.S., 2003. Lipid and fatty acid composition of Antarctic shrimp eggs (Decapoda: Caridea). Polar Biol. 26, 55-61.

Graeve, M., Kattner, G., Piepenburg, D., 1997. Lipids in Arctic benthos: does the fatty acid and alcohol composition reflect feeding and trophic interactions? Polar Biol. 18, 53-61.

Hagen, W., 1988. Zur Bedeutung der Lipide im antarktischen Zooplankton. Ber. Polarforsch. 49, 1-129 ((in German) [English version (1989): On the significance of lipids in Antarctic zooplankton. Canadian Translation Fish. Aquat. Sci. 5458, 1-149.]).

Herring, P.J., 1974. Size, density and lipid content of some decapod eggs. Deep-Sea Res. 21, 91-94.

Holland, D.L., 1978. Lipid reserves and energy metabolism in the larvae of benthic marine invertebrates. In: Malins, D.C., Sargent, J.R. (Eds.), Biochemical and Biophysical Perspectives in Marine Biology. Academic Press, London, pp. 85-123.

Kattner, G., Fricke, H.S.G., 1986. Simple gas-liquid chromatographic method for the simultaneous determination of fatty acids and alcohols in wax esters of marine organisms. J. Chromatogr. 361, 263-268.

Kattner, G., Hagen, W., 1995. Polar herbivorous copepods - different pathways in lipid biosynthesis. ICES J. Mar. Sci. 52, 329-335.

Kattner, G., Wehrtmann, I.S., Merck, T., 1994. Interannual variations of lipids and fatty acids during larval development of Crangon spp. in the German Bight, North Sea. Comp. Biochem. Physiol. 107B, 103-110.

Kattner, G., Hagen, W., Graeve, M., Albers, C., 1998. Exceptional lipids and fatty acids in the pteropod Clione limacina (Gastropoda) from both polar oceans. Mar. Chem. 61, 219-228.

Knox, G.A., 1994. The Biology of the Southern Ocean. Cambridge Univ. Press, Cambridge, UK, pp. 1-444.

Levine, D.M., Sulkin, S.D., 1984. Nutritional significance of long-chain polyunsaturated fatty acids to the zoeal development of the brachyuran crab, Eurypanopeus depressus (Smith). J. Exp. Mar. Biol. Ecol. 81, $211-223$.

Lovrich, G.A., 1997. La pesquería mixta de las centollas Lithodes santolla y Paralomis granulosa (Anomura: Lithodidae) en Tierra del Fuego, Argentina. Invest. Mar. (Valparaíso) 25, 41-57.

Lovrich, G.A., Thatje, S., Calcagno, J.A., Anger, K., Kaffenberger, A., 2003. Changes in biomass and chemical composition during lecithotrophic larval development of the southern king crab, Lithodes santolla (Molina). J. Exp. Mar. Biol. Ecol. 288, 65-79. 
Lowry, D.H., Rosenberg, N.J., Farr, A.L., Randall, R.J., 1951. Protein measurement with the folin phenol reagent. J. Biol. Chem. 193, 265-275.

McLaughlin, P.A., Anger, K., Kaffenberger, A., Lovrich, G.A., 2001. Megalopal and early juvenile development in Lithodes santolla (Molina, 1782) (Decapoda: Anomura; Paguroidea: Lithodidae), with notes on zoeal variations. Invertebr. Reprod. Dev. 40, 53-67.

McLaughlin, P.A., Anger, K., Kaffenberger, A., Lovrich, G.A., 2003. Larval and early juvenile development in Paralomis granulosa (Jacquinot) (Decapoda: Anomura: Paguroidea: Lithodidae), with emphasis on abdominal changes in megalopal and crab stages. J. Nat. Hist. (in press).

Morais, S., Narciso, L., Calado, R., Nunes, M.L., Rosa, R., 2002. Lipid dynamics during the embryonic development of Plesionika martia martia (Decapoda; Pandalidae), Palaemon serratus and Palaemon elegans (Decapoda; Palaemonidae): relation to metabolic consumption. Mar. Ecol. Prog. Ser. 242, 195-204.

Olsen, R.E., Henderson, R.J., 1989. The rapid analysis of neutral and polar marine lipids using double-development HPTLC and scanning densitometry. J. Exp. Mar. Biol. Ecol. 129, 189-197.

Petersen, S., Anger, K., 1997. Chemical and physiological changes during the embryonic development of the spider crab, Hyas araneus L. (Decapoda: Majidae). Comp. Biochem. Physiol. 117B, 299-306.

Rabalais, N.N., Gore, R.H., 1985. Abbreviated development in decapods. In: Wenner, A.M. (Ed.), Larval Growth. Crustacean Issues, vol. 2. Balkema, Rotterdam, pp. 67-126.

Rainuzzo, J.R., Reitan, K.I., Olsen, Y., 1997. The significance of lipids at early stages of marine fish: a review. Aquaculture 155, 103-116.

Shirley, T.C., Zhou, S., 1997. Lecithotrophic development of the golden king crab Lithodes aequispinus (Anomura: Lithodidae). J. Crustac. Biol. 17, 207-216.

Thatje, S., Calcagno, J.A., Lovrich, G.A., Sartoris, F.J., Anger, K., 2003. Extended hatching rhythms in the Subantarctic lithodid crabs Lithodes santolla and Paralomis granulosa (Crustacea: Decapoda: Lithodidae). Helgol. Mar. Res. (in press).

Wehrtmann, I.S., Graeve, M., 1998. Lipid composition and utilization in developing eggs of two tropical marine caridean shrimps (Decapoda: Caridea: Alpheidae, Palaemonidae). Comp. Biochem. Physiol. 121B, 457-463.

Wehrtmann, I.S., Kattner, G., 1998. Changes in volume, biomass, and fatty acids of developing eggs in Nauticaris magellanica (Decapoda: Caridea): a latitudinal comparison. J. Crustac. Biol. 18, 413-422. 